\title{
PROCESSING SUBSTANDARD MATERIALS OF MAGNESIUM-THERMAL ZIRCONIUM PRODUCTION
}

\author{
M.M. Pylypenko ${ }^{I}$, T.B. Yanko ${ }^{2}$, Yu.S. Stadnik ${ }^{1}$, A.O. Drobyshevska ${ }^{1}$ \\ ${ }^{1}$ National Science Center "Kharkov Institute of Physics and Technology", Kharkiv, Ukraine; \\ ${ }^{2}$ Public Joint Stock Company "Titanium institute”, Zaporizhzhya, Ukraine \\ E-mail:tb_yanko@ukr.net
}

This paper describes results of study processing of substandard materials and waste of magnesium-thermal production of spongy zirconium to determine the optimal methods of zirconium recycling. The optimal methods of processing that will allow reuse of substandard materials and waste in the process of magnesium-thermal production of sponge zirconium with the content of impurities at the level of world standards are determined.

\section{INTRODUCTION}

Zirconium alloys are widely used as nuclear fuel clad materials and core structures in water-cooled nuclear power reactors due to its strong corrosion resistance properties and excellent low absorption crosssection for thermal neutrons [1].

For nuclear reactor applications the zirconium alloys (M5, Zirlo, Zircaloy-2, Zircaloy-4, MDA, NDA) produce using zirconium sponge produced by magnesium-thermal method [1-3]. Method of magnesium-thermal recovery of zirconium tetrachloride (the Kroll process) is most widely used to produce zirconium metal in the world practice. Zirconium sponge is produced by this method which is based on the reduction of gaseous zirconium tetrachloride with liquid magnesium in an oxygen-free environment in a combination batch process. It is then separated from the excess magnesium and magnesium chloride by vacuum distillation and finally melted in a vacuum ingot form.

The results of feasibility study showed that prime price of zirconium, got on technology of magnesiumthermal reduction of tetrachloride of zirconium, less than, and process of receipt - more rapid with providing of considerable energy-savings [4]. Technology of magnesium-thermal reduction consists of the following steps: chlorination of zircon, separation of zirconium and hafnium chlorides, reduction of zirconium tetrachloride, purification of recovery products by vacuum separation, vacuum treatment of sponge zirconium and processing into a commodity product [2, 3, 5-7].

The need for utilization of substandard materials is one of the problems in developing the technology of magnesium-thermal production of sponge zirconium, which cannot be used in the manufacture of zirconium sponge. Substandard materials and waste are generated at various stages of metal production and fabrication.

The substandard materials and wastes generated during the metal production is an integral part of the magnesium-thermal production of zirconium. The number of these materials depends on the observance of technological regimes for the production of both zirconium tetrachloride and sponge zirconium. Therefore, the definition of methods and technologies for utilization of substandard materials and waste has an important impact on the economic parameters of the production of spongy zirconium, which require more detailed research to select the most efficient methods of processing.

The purpose of the work was to study processes for the processing of substandard materials and waste magnesium-thermal production of sponge zirconium to determine the optimal methods of processing, which would allow them to be reused in the process of magnesium-thermal obtaining of sponge zirconium with the content of impurities in sponge zirconium at the level of world standards.

\section{SUBSTANDARD MATERIALS OF MAGNESIUM-THERMAL ZIRCONIUM PRODUCTION}

Raw materials always contain certain impurities, even in small quantities, the equipment may have certain disadvantages, and deviations in the modes of technological processes always take place - all this leads to the generation of substandard materials and waste.

An analysis of the process for the production of zirconium has shown that the main substandard products and wastes generated during the magnesiumthermal recovery of zirconium tetrachloride are chloride and metal substandard materials, such as:

- residues of zirconium tetrachloride which did not reacted in the recovery apparatus;

- lower zirconium chlorides, formed in the cold zones of the reactor, on the retort flanges;

- lower zirconium chlorides, formed in the event of a magnesium deficiency in the process of recovery and deviations in technology of recovery process;

- lower and lateral portions of the zirconium block in which the impurities from the raw material can accumulate;

- residues of the separation and comminution of the spongy zirconium block;

- blocks or parts of the sponge zirconium block, formed as a result of violation of technological regimes of recovery and vacuum separation.

In addition, zirconium tetrachloride after long-term storage or storage in inappropriate conditions should be considered substandard materials too. In this case the zirconium chloride is saturated with moisture and oxychloride is formed, which is not recovered during the production of sponge zirconium and reduces the productivity of the process, as well as increases the 
content of harmful impurities, especially oxygen, in sponge zirconium.

If metal substandard materials of magnesiumthermal production have high quality they can be used in iodide refining process as initial materials. All other waste has a significant content of impurities, so they must be subjected to re-chlorination and recovery.

The particle size of zirconia (zirconium dioxide), which is subject to chlorination, should not normally exceed $100 \mu \mathrm{m}$, therefore, it is necessary to provide for the processing of substandard products and waste of magnesium-thermal production to the appropriate fractional composition. This is possible with the use of hydrogenation-dehydrogenation technology of zirconium and zirconium-containing wastes and followed comminution. Using this method does not lead to a significant increase in the content of impurities, does not require significant constructional and technological changes in magnesium-thermal technology of recovery of zirconium tetrachloride and in the process of further processing of sponge zirconium and the production of zirconium alloys for nuclear energy.

Based on the analysis of the magnesium-thermal process of recovery of zirconium tetrachloride, it can be noted that the main types of waste are chloride zirconium compounds, which are generated as a result of such factors as the features of the technology of the recovery process, deviations of the modes of obtaining spongy zirconium; violation of storage conditions of raw materials; as well as metal zirconium waste generated during the processing of a sponge zirconium block and as a result of violation of the conditions of the processes of recovery and vacuum separation.

The main method of processing substandard materials and waste of magnesium-thermal production of sponge zirconium can be considered re-chlorination, purification and recovery, and for high-quality wastes iodide refining process.

\section{EXPERIMENTAL PROCEDURES AND DISCUSSION \\ 2.1. HYDROLYSIS OF ZIRCONIUM CHLORIDES}

Hydrolysis of zirconium chlorides use for the processing of chloride wastes of magnesium-thermal process of the zirconium production. Hydrolysis is a chemical reaction in which one substance reacts with water to produce another.

In order to obtain qualitative raw materials that can use for chlorination, it is necessary substandard chloride materials of magnesium-thermal production (residues of unreacted zirconium tetrachloride, lower chlorides of the reduction process, and zirconium tetrachloride, partially damaged, due to improper storage conditions) to process by hydrolysis by an exothermic reaction:

$$
\mathrm{ZrCl}_{4}+\mathrm{H}_{2} \mathrm{O} \rightarrow \mathrm{ZrOCl}_{2}+2 \mathrm{HCl}
$$

Hydrolyzed chloride dissolves in water. Then crystallization of zirconium oxychloride is carried out: zirconium oxychloride is easily obtained from the aqueous solution by evaporation and subsequent crystallization during cooling. After evaporation, zirconium oxychloride crystalline hydrate is formed $\mathrm{ZrOCl}_{2} \cdot 8 \mathrm{H}_{2} \mathrm{O}$.

When heated, zirconium oxychloride $\mathrm{ZrOCl}_{2} \cdot 8 \mathrm{H}_{2} \mathrm{O}$ can simultaneously be dehydrated and hydrolyzed, and the rate and degree of the reaction of dehydration and thermo hydrolysis is determined by the ratio of the partial pressures of $\mathrm{HCl}$ and $\mathrm{H}_{2} \mathrm{O}$, temperature and kinetic regularities. Depending on these factors, the composition of the intermediate products and the stagedness of the processes occurring during the heating of the main chlorides substantially changes.

Research has shown that the resulting crystalline hydrate should be calcined at a temperature of $300 \ldots 600{ }^{\circ} \mathrm{C}$ and obtaining zirconia $\left(\mathrm{ZrO}_{2}\right)$ by reaction:

$$
\mathrm{ZrOCl}_{2} \cdot 8 \mathrm{H}_{2} \mathrm{O}=\mathrm{ZrO}_{2}+2 \mathrm{HCl}+7 \mathrm{H}_{2} \mathrm{O} \text {. }
$$

Thus, zirconium dioxide was produced from chloride waste. The content of impurities in the obtained zirconium dioxide complies with the requirements for the quality of the raw materials entering the chlorination (Table 1).

Table 1

Composition of obtained zirconium dioxide

\begin{tabular}{|c|c|c|c|}
\hline Impurity & wt.\% & Impurity & wt.\% \\
\hline $\mathrm{Fe}$ & 0.016 & $\mathrm{Al}$ & 0.014 \\
\hline $\mathrm{Ti}$ & 0.004 & $\mathrm{Mg}$ & 0.05 \\
\hline $\mathrm{Si}$ & 0.26 & $\mathrm{Na}$ & 0.13 \\
\hline $\mathrm{Ca}$ & 0.3 & - & - \\
\hline
\end{tabular}

Thus, it was found that the processing of chlorine substandard products of magnesium-thermal production of zirconium can be accomplished by hydrolysis of zirconium chlorides with following decomposition of zirconium oxychloride into high-quality $\mathrm{ZrO}_{2}$.

\subsection{HYDROGENATION OF SUBSTANDARD METAL PRODUCTS}

For the successful chlorination of metal remnants containing zirconium, the raw material must be comminuting, providing the necessary fractional composition of the raw material. Zirconium is a sufficiently hard substance that is difficult to comminute. And waste and substandard materials, due to the increased content of impurities, have even higher strength characteristics.

Hydrogen saturation of zirconium allows the material to be qualitatively comminuted due to the effect of zirconium embrittlement and reduces the safety performance for dry zirconium powders [8, 9].

Saturation with hydrogen makes it possible to obtain zirconium powders of a wide granulometric composition. The basis of hydrogenationdehydrogenation of zirconium is the ability of hydrogen to dissolve in the metal, which causes a significant increase the embrittlement of zirconium when saturated with hydrogen. The dissolution of hydrogen in zirconium increases the volume and density of the 
material decreases linearly to $4.92 \mathrm{~g} / \mathrm{cm}^{3}$ [9]. The process of hydrogenation is a direct saturation of zirconium with hydrogen, which occurs at temperatures above $300{ }^{\circ} \mathrm{C}$ by reaction:

$$
\mathrm{Zr}+\mathrm{H}_{2} \rightarrow \mathrm{ZrH}_{2} \text {. }
$$

Zirconium materials of various types (sponge, rods, shavings, etc) can be use to produce zirconium hydride. Studies have shown that for the process of hydrogenation of zirconium to be of high quality and fast it is necessary that the optimal linear dimensions of the samples should not exceed $50 \mathrm{~mm}$.

Hydration processes were carried out on a laboratory universal vacuum setup. The prepared material was loaded to the reactor and heated to $300 \ldots 600{ }^{\circ} \mathrm{C}$, the retort was filled with hydrogen, held out and cooled in an atmosphere of hydrogen. Samples of zirconium with a mean hydrogen content of $3.2 . .3 .4 \mathrm{wt} . \%$ were obtained as a result of process of hydrogenation of zirconium.

Comminuting of zirconium hydride was carried out in a ball mill, as the simplest of design and maintenance, and which provides the yield of powder in accordance with specified conditions. To prevent the contamination of zirconium by iron and other impurities, the drum is lined with sheet titanium, and the working bodies are also used from titanium. Parameters of the laboratory ball mill: diameter $190 \mathrm{~mm}$, length $320 \mathrm{~mm}$, capacity 91 , speed of $60 \ldots 100 \mathrm{rev} / \mathrm{min}$, diameter of balls $30 \ldots 50 \mathrm{~mm}$. To prevent the formation of hazardous concentrations of zirconium dust and zirconium hydride, the drum was vacuumed to a pressure of $1 \cdot 10^{-1} \mathrm{~mm} \mathrm{Hg}$ and filled with argon.

Determination of the influence of the ball load on the speed of comminuting showed that the most productive is the work of the mill at a ratio of $2: 1$ weight of balls and material that is comminuted [10]. The research has established the dependence of the fractional composition of the zirconium hydride, which is comminuted, on the ball load. By adjusting the weight ratio of the balls and the hydride it is possible to achieve the maximum yield of the given fraction.

Studies have shown that the degree of comminuting is influenced by the hydrogen content and the duration of the mill. The effect of hydrogen content in the hydrogenated material on the degree of its comminuting (time of comminuting - $40 \mathrm{~min}$ ) is shown in Fig. 1 . Increasing the hydrogen content in hydrogenated zirconium increases the yield of fine powder particles. Using the data shown in Fig. 1, it is possible to determine the content of hydrogen in zirconium to obtain the hydride of the required dispersion. This dependence is characteristic both for pure zirconium and for zirconium materials of different origin.

The researches have established that significant influence on the yield of fractions has the duration of comminuting, with increasing the duration of the process the yield of fine fractions increase too, however, it is not possible to achieve a significant increase in the amount of fine fraction without increasing the hydrogen content in the comminuting product. In experiments, a small amount of zirconium was used, so comminuting was carried out on a dry principle. But in the conditions of industrial use for the purpose of ensuring fire and explosion hazard, it is necessary to carry out the processes of comminuting in a liquid.

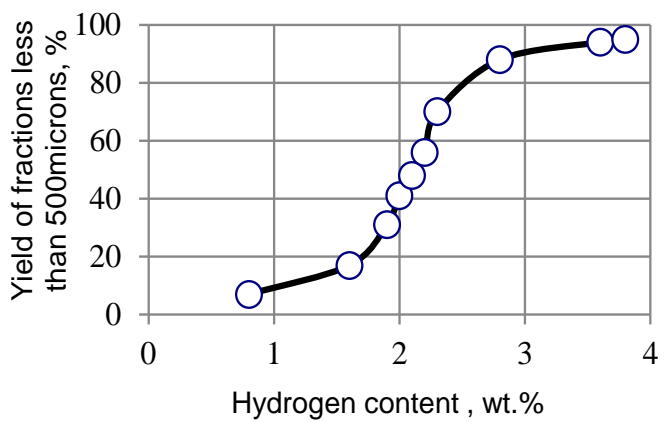

\section{Fig. 1. Influence of hydrogen content in hydrogenated material on the degree of its comminuting}

After comminuting, degassing of zirconium hydride at a temperature of $750 \ldots 800{ }^{\circ} \mathrm{C}$ was carried out to the residual hydrogen content, no more than $0.2 \mathrm{wt} . \%$.

Thus, the use of the method of hydrogenation of metal wastes of zirconium production with subsequent comminuting and dehydrogenation allows to obtain zirconium powders of the required dispersion.

\subsection{OBTAINING OF ZIRCONIUM TETRACHLORIDE}

Zirconium dioxide chlorination technology is used to produce zirconium tetrachloride. Chlorination of zirconium dioxide has high energy consumption, occurs with heat consumption - for the reaction of interaction of zirconium dioxide with chlorine it is required $\sim 102 \mathrm{~kJ}$ per 1 mole of zirconium dioxide. When zirconium is added to the charge, a large amount of thermal energy is released, because the reaction of the interaction of metal zirconium with chlorine is exothermic and occurs with the release of $\sim 863 \mathrm{~kJ}$ of heat per 1 mole of zirconium, which reduces the heat consumption for the chlorination process.

The reaction

$$
\mathrm{ZrO}_{2}+\mathrm{C}+2 \mathrm{Cl}_{2}=\mathrm{ZrCl}_{4}+\mathrm{CO}_{2}
$$

is endothermic, the thermal effect of the reaction is determined by the change in the enthalpy of formation and the heat capacity between the final and initial compounds, taking into account the temperature $Q_{\text {reac }}=-102.303 \mathrm{~kJ} / \mathrm{mole} \mathrm{ZrO}_{2}$.

The reaction

$$
\mathrm{Zr}+2 \mathrm{Cl}_{2}=\mathrm{ZrCl}_{4}
$$

is exothermic, the thermal effect of the reaction is $Q_{\text {reac }}=+863.048 \mathrm{~kJ} /$ mole $\mathrm{Zr}$.

The chlorination technology described in [11] was used to study the process for the production of zirconium tetrachloride. The charge for chlorination consisted of zirconium powder, zirconium dioxide, comminutined to a particle size of $0.1 \mathrm{~mm}$, carbonaceous reducing agent and alkali metal chlorides. The mixture thus obtained was placed in a laboratory installation for chlorination. 
The installation for chlorination (Fig. 2) consists of a chlorinator located in a shaft-type electric furnace, a chlorine supply system, a charge loading container, a condenser with a built-in sleeve filter and a receiver tank for collecting zirconium tetrachloride. Before chlorination, a mixture of $\mathrm{NaCl}$ and $\mathrm{KCl}$ salts was loaded into the chlorinator at $50 \%$ of the working volume, melted and the melt heated to a predetermined temperature. After heating to a predetermined temperature, the melt was blown down with chlorine for
$10 \ldots 15 \mathrm{~min}$, then the mixture, which consist zirconium dioxide, carbonaceous reducing agent, alkali metal chlorides and zirconium powder, was charged to the surface of the melt of alkali metal chlorides, in $100 \mathrm{~g}$ portions every $20 \mathrm{~min}$. Such portions of the mixture ensured the fluidity of the working melt after loading. The steam-gas mixture, which is formed and consists of vapors of zirconium tetrachloride, impurity chlorides of the accompanying metals and gaseous chlorination products, enters the condenser, where it is condensed.

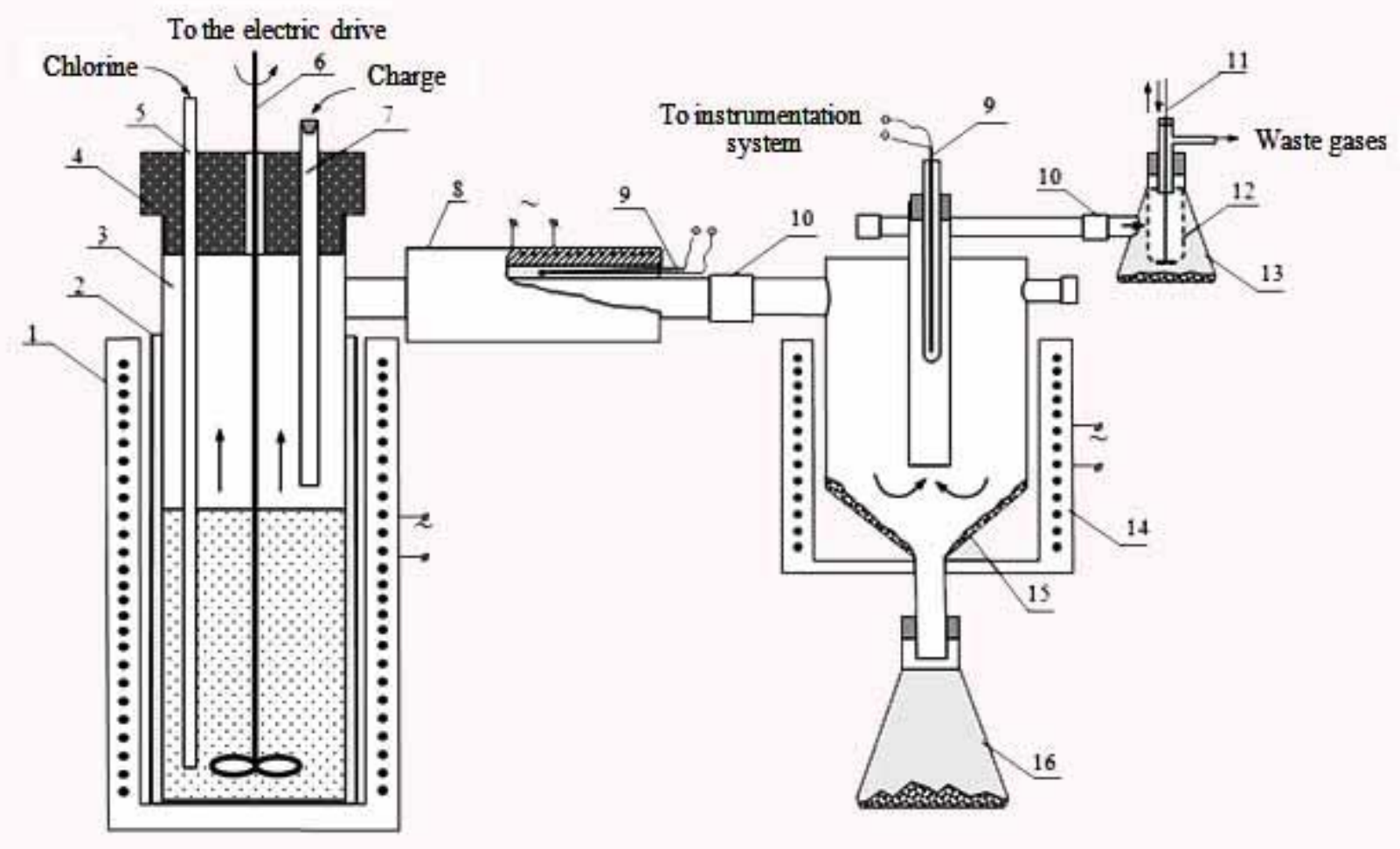

Fig. 2. Scheme of the laboratory installation for chlorination:

1, 14 - electric furnace; 2 - a glass; 3 - chlorinator; 4 - head; 5 - chlorine supply;

6 -mixer; 7 -pipe connection; 8-heater; 9-thermocouple; 10 -cuff; 11 -shaker;

12 - sleeve; 13 - filter; 15 - chamber condenser; 16 - receiver

During the chlorination process the temperature in the chlorinator was determined using a thermocouple, the chlorine feed rate using a rotameter, the presence of chlorine in the exhaust gases by the release of iodine from a marker with potassium iodide, as well as the mass of obtained zirconium tetrachloride was determined. The electric power of the furnace was varied from experiment to experiment, depending on the content of zirconium in the composition of the charge and was regulated by changing the supply voltage. After the completion of the experiment, the supply of chlorine was stopped, the installation was dismantled, and the melt with chlorinators was decanted, cooled and analyzed for the content of zirconium dioxide and other components. The obtained zirconium tetrachloride was analyzed for the content of the main impurities.
According to the analysis of the conditions and processes of chlorination (Table 2), an optimal ratio of zirconium dioxide, carbon reducing agent, the amount of chloride salts and zirconium powder was determined which provide the best yield of the product - 7.5:0.75: $0.75: 2$, respectively. The previously performed studies allowed to determine the optimum temperature of the chlorination process for laboratory equipment, which is $750 \ldots 800{ }^{\circ} \mathrm{C}$, and the ratio of salts $\mathrm{NaCl}: \mathrm{KCl}=1: 1$. Zirconium dioxide for chlorination processes Nos. 5-7 (see Table 2) was obtained by processing substandard chloride products of zirconium sponge production. The chemical composition of the obtained technical zirconium tetrachloride (TZT) is given in Table 3 . The data given in lines $3-5$ of this table are for zirconium tetrachloride obtained by recycling waste. 
Table 2

Conditions and results of chlorination processes

\begin{tabular}{|c|c|c|c|c|c|c|}
\hline \multirow{2}{*}{$\begin{array}{l}\text { Process } \\
\text { No. }\end{array}$} & \multirow{2}{*}{$\begin{array}{c}\text { Ratio } \\
\mathrm{ZrO}_{2}: \text { coke }: \mathrm{KCl}-\mathrm{NaCl}: \mathrm{Zr}\end{array}$} & \multirow{2}{*}{$\begin{array}{l}\text { Chlorination } \\
\text { time, } \mathrm{h}\end{array}$} & \multirow{2}{*}{$\begin{array}{l}\text { Chlorination } \\
\text { rate, } \mathrm{g} / \mathrm{h}\end{array}$} & \multicolumn{2}{|c|}{ Obtained by weight, $g$} & \multirow{2}{*}{$\begin{array}{l}\text { Yield, } \\
\%\end{array}$} \\
\hline & & & & $\mathrm{TZT}$ & $\mathrm{Zr}$ in $\mathrm{TZT}$ & \\
\hline 1 & $8: 1: 1: 0$ & 5.50 & 318.2 & 1750 & 684 & 80.9 \\
\hline 2 & $8: 0.8: 0.8: 0$ & 8.50 & 258.8 & 2207 & 860 & 87.3 \\
\hline 3 & $9: 1: 0.5: 0.5$ & 11.0 & 251.2 & 2762 & 1081 & 88.3 \\
\hline 4 & $7: 1: 0.5: 0.1$ & 5.50 & 369.6 & 2034 & 795 & 82.7 \\
\hline 5 & $8: 1: 0.5: 0.5$ & 4.67 & 357.0 & 1665 & 652 & 88.1 \\
\hline 6 & $7.5: 0.75: 0.75: 2$ & 9.00 & 285.6 & 2560 & 1005 & 90.5 \\
\hline 7 & $7.5: 0.8: 0.8: 1.8$ & 6.75 & 259.3 & 1752 & 684 & 92.4 \\
\hline
\end{tabular}

Table 3

The chemical composition of zirconium tetrachloride

\begin{tabular}{|c|c|c|c|c|c|c|c|c|c|}
\hline \multirow{2}{*}{ No. } & \multicolumn{9}{|c|}{ Content of the component, wt.\% } \\
\hline & $\mathrm{Al}$ & $\mathrm{Fe}$ & $\mathrm{Ca}$ & $\mathrm{Si}$ & $\mathrm{Ti}$ & $\mathrm{Cr}$ & $\mathrm{Mg}$ & $\mathrm{Na}$ & $\mathrm{C}$ \\
\hline 1 & 0.016 & $<0.10$ & 0.019 & 0.041 & 0.052 & 0.0028 & $<0.01$ & 0.21 & 0.051 \\
\hline 2 & 0.015 & 0.098 & 0.044 & 0.029 & 0.011 & 0.0036 & 0.0013 & $3 \cdot 10^{-4}$ & - \\
\hline 3 & 0.007 & $<0.10$ & 0.025 & 0.033 & $2 \cdot 10^{-4}$ & 0.0031 & 0.029 & 0.15 & 0.062 \\
\hline 4 & 0.0080 & $<0.10$ & 0.0074 & 0.014 & 0.016 & 0.0096 & 0.0044 & 0.064 & 0.056 \\
\hline 5 & 0.0068 & 0.091 & 0.025 & 0.030 & $2 \cdot 10^{-4}$ & 0.0021 & 0.018 & 0.17 & 0.047 \\
\hline
\end{tabular}

From the data given in Table 3 it can be noted that the use of zirconium tetrachloride produced from substandard chlorine products of magnesium-thermal production of spongy zirconium is justified, because it are of the same quality as zirconium tetrachloride produced according to the standard procedure. Under these conditions, it is acceptable to use metallic substandard products of magnesium-thermal zirconium sponge production. In addition, the use of fine zirconium as a thermal additive contributes to a reduction in the energy consumption of chlorination [11] and slightly increases the yield of zirconium tetrachloride (see processes 5-7 in Table 2).

The purification process of zirconium tetrachloride by sublimation is the next step in the technological chain after chlorination. The process of sublimation of vapor of technical zirconium tetrachloride was carried out through a layer of charcoal. The amount of coal was $10 \%$ of the weight of the loaded technical zirconium tetrachloride to the sublimation reactor. The temperature at which the evaporation of zirconium tetrachloride begins is $333^{\circ} \mathrm{C}$. Under such conditions, the sublimation rate reaches $500 \ldots 550 \mathrm{~g} / \mathrm{h}$. The purification process was carried out until the temperature in the vapor stream of zirconium tetrachloride began to rise significantly, and when it reached $500{ }^{\circ} \mathrm{C}$, the purification process was stopped. The purification was also carried out through the filter layers of the salt melt of different composition.

The chemical composition of the obtained purified Zirconium tetrachloride in comparison with the typical products of the world-leading manufacturers ATI (Allegheny Technologies Incorporated), USA [12] and CEZUS (Areva), France [13] are shown in Table 4. As can be seen from the table, according to the results of chemical analysis, the quality of purified zirconium tetrachloride is acceptable even at the level of world manufacturers. The quality of zirconium tetrachloride, obtained by processing substandard products of magnesium-thermal production of spongy zirconium, is not inferior, and in some indicators exceeds the purified zirconium tetrachloride, obtained by conventional technology. This can be explained by the fact that substandard products have previously been partially 
purified from the main impurities, and their re-purifying has shown better results. Insignificant excess of some indicators can be explained by laboratory volumes of production and the imperfection of laboratory equipment. The quality of zirconium tetrachloride and its final yield should increase in the transition to industrial or semi-industrial production of zirconium tetrachloride for the needs of magnesium-thermal zirconium sponge production.

The chemical composition of purified zirconium tetrachloride

\begin{tabular}{|c|c|c|c|c|}
\hline \multirow{2}{*}{ Impurity } & \multicolumn{4}{|c|}{ Content of the component in zirconium tetrachloride, wt.\% } \\
\cline { 2 - 5 } & $\begin{array}{c}\text { From substandard } \\
\text { products }\end{array}$ & $\begin{array}{c}\text { According to the standard } \\
\text { procedure }\end{array}$ & ATI & CEZUS \\
\hline $\mathrm{Al}$ & $0.002 \ldots 0.0072$ & $0.0020 \ldots 0.0070$ & $0.005 \ldots 0.01$ & $<0.0050$ \\
\hline $\mathrm{Fe}$ & $0.0040 \ldots 0.0056$ & $0.0042 \ldots 0.0200$ & $0.05 \ldots 0.1$ & $<0.0040$ \\
\hline $\mathrm{Si}$ & $0.0091 \ldots 0.0170$ & $0.0120 \ldots 0.0230$ & $0.0025 \ldots 0.01$ & $<0.0020$ \\
\hline $\mathrm{Ti}$ & $0.0002 \ldots 0.0011$ & $0.0002 \ldots 0.0023$ & $0.0050 \ldots 0.02$ & $<0.0010$ \\
\hline $\mathrm{Cr}$ & $0.0003 \ldots 0.0007$ & $0.0003 \ldots 0.0031$ & - & $<0.0010$ \\
\hline $\mathrm{Mg}$ & $<0.0010$ & $<0.0010$ & - & $<0.0010$ \\
\hline
\end{tabular}

Thus, the addition of zirconium powder and zirconium dioxide obtained after the processing of substandard products and waste to the charge for chlorination allows to obtain high-quality zirconium tetrachloride, which is better zirconium tetrachloride in some indicators, which was obtained by conventional technology. In addition, the use of fine zirconium as a thermal additive reduces energy consumption for chlorination and slightly increases the yield of zirconium tetrachloride.

\section{CONCLUSIONS}

Processes of processing of chloride substandard products of magnesium-thermal production of zirconium by hydrolysis of zirconium chlorides with subsequent decomposition of zirconium oxychloride into high-quality zirconium dioxide $\mathrm{ZrO}_{2}$ and processing of metallic substandard products of magnesium-thermal production of zirconium by hydrogenation and comminuting are investigated. It has been established that the quality of zirconium tetrachloride, obtained by processing substandard products of magnesium-thermal production of zirconium spongy, exceeds in some indicators zirconium tetrachloride, obtained by conventional technology. The results of researches are recommended for use in utilization of substandard products and waste of magnesium-thermal production of sponge zirconium.

\section{REFERENCES}

1. В.М. Ажажа, П.Н. Вьюгов, С.Д. Лавриненко и др. Цирконий $u$ его сплавы: технологии производства, области применения. Харьков: ННЦ ХФТИ, 1998, 98 с.
2. M.M. Pylypenko. High pure zirconium // BAHT. Серия «Вакуум, чистые материаль, сверхпроводники». 2018, №1, с. 3-8.

3. Н.Н. Пилипенко. Получение циркония ядерной чистоты // ВАНT. Серия «Физика радиаџионных повреждений и радиационное материаловедение». 2008, № 2, с.66-72.

4. А.К. Шиков, А.Д. Никулин, А.В. Никулина и др. Современное состояние и перспективы развития производства циркония и его сплавов и изделий из них // Физика и химия обработки материалов. 2001, №6, c. 5-14.

5. Пат. 90853 Україна, МПК51 С22В34/14. Спосіб магнієтермічного отримання губчастого цุирконію / Яценко О.П., Сущинський О.Д., Янко Т.Б., Лавриненко С.Д., Пилипенко М.М. Власник ДП «ДНДП Інститут титану»; заявл. 20.01.2014; опубл. 10.06.2014, Бюл. № 11.

6. Пат. 82174 Україна, МПК51 С22В34/14. Пристрій для магнієтермічного відновлення тетрахлориду цирконію / Яценко О.П., Сущинський О.Д., Щербань Р.А., Янко Т.Б., Лавриненко С.Д., Пилипенко М.М. Власник ДП «ДНДП Інститут титану»; заявл. 24.01.2013; опубл. 25.07.2013, Бюл. №14.

7. Р.А. Щербань, Я.А. Шаповалов, А.П. Яценко и др. Исследование технологии магниетермического получения губчатого циркония на экспериментальных установках // ВАНТ. Серия «Вакуум, чистые материаль, сверхпроводники». 2011, №6, c. $48-51$.

8. О.И. Соловей. Пожаровзрывоопасность гидридов переходных металлов при хранении и транспортировке водорода // Интегрированные технологии и энергосбережение. 2004, №1, с. 111114. 
9. Металлургия ичиркония: Пер. с англ. / Под ред. Г.А. Меерсона, Ю.В. Гагаринского. М.: «Иностр. лит-ра», 1959, 419 с.

10. С.С. Кипарисов. Порошковая металлургия: Учеб. для техникумов. М.: «Металлургия», 1991, $431 \mathrm{c}$.

11. Пат. 61827 Україна, С22В34/00. Спосіб одержання тетрахлориду изирконію / Никоненко О.П., Литвинова О.М., Сидоренко С.А., Кузіна Л.К., Степаніщева Д.Ф., Петрунько А.М.,
Сущинський О.Д. Заявник і патентовласник ДП «ДНДП Інститут титану»; заявл. 14.02.2011; опубл. 25.07.2011, Бюл. №14.

12. Zirconium Tetrachloride Reactor Grade. https:// www.atimetals.com/Products/zirconium- tetrachloride reactor-grade.

13. Zirconium Free Hafnium Tetrachloride Specification Grade 1004 // CEZUS Jarrie Plant. CEZ. JA. SAQM.1004, Issue 8 of Feb.08, 2005.

Article received 31.05.2019

\section{ПЕРЕРАБОТКА НЕКОНДИЦИОННЫХ ПРОДУКТОВ МАГНИЕТЕРМИЧНОГО ПРОИЗВОДСТВА ЦИРКОНИЯ}

\section{Н.Н. Пилипенко, Т.Б. Янко, Ю.С. Стадник, А.А. Дробышевская}

Приведены результаты исследования переработки некондиционных продуктов и отходов магниетермического производства губчатого циркония для определения оптимальных методов переработки циркония. Определены оптимальные методы переработки, позволяющие повторно использовать некондиционные продукты и отходы в процессе магниетермического производства губчатого циркония с содержанием примесей на уровне мировых стандартов.

\section{ПЕРЕРОБКА НЕКОНДИЦІЙНИХ ПРОДУКТІВ МАГНІЕТЕРМІЧНОГО ВИРОБНИЦТВА ЦИРКОНІЮ}

\section{М.М. Пилипенко, Т.Б. Янко, Ю.С. Стаднік, А.О. Дробишевська}

Наведено результати дослідження переробки некондиційних продуктів і відходів магнієтермічного виробництва губчастого цирконію для визначення оптимальних методів переробки цирконію. Визначено оптимальні методи переробки, що дозволяють повторно використовувати некондиційні продукти та відходи в процесі магнієтермічного виробництва губчастого цирконію 3 вмістом домішок на рівні світових стандартів. 